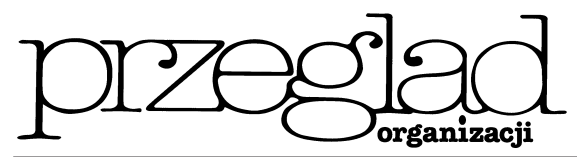

\title{
Możliwości kształtowania wartości produktu przez producentów - wybrane aspekty
}

https://doi.org/10.33141/po.2005.78.14

Przegląd Organizacji, Nr 7/8 (786/787), 2005, ss. 54-57 www.przegladorganizacji.pl Towarzystwo Naukowe Organizacji i Kierownictwa (TNOiK)

\section{$\overline{\text { Magdalena Ankiel-Homa, Tomasz Olejniczak }}$}

Permanentne zmiany otoczenia i wzrost wymagań konsumentów wraz ze wzrostem liczby produktów i oferentów na rynku powodują, że przedsiębiorstwa poszukują nowych sposobów uzyskiwania przewagi konkurencyjnej. Coraz częściej docenia się możliwość skutecznego rywalizowania z konkurentami poprzez zwiększenie wartości produktu dla konsumenta. Przez wartość produktu rozumie się najczęściej postrzegane przez nabywcę całkowite korzyści, które może uzyskać dzięki produktowi, pomniejszone o postrzegane koszty nabycia i posiadania. Konsumenci posiadaja pewną pierwotną wewnętrzną koncepcję „właściwego" stosunku korzyści do kosztów. Porównując dostępne alternatywy, nabywcy wybierają takie oferty produktowe, które ich zdaniem zapewnią im największą wartość. Dlatego też wartość produktu jest kategorią subiektywną, postrzeganą względem oferty konkurentów ${ }^{1)}$.

Szeroki portfel znaczeniowy wartości produktu wynika z faktu znamiennej różnorodności potrzeb odczuwanych przez konsumentów, jak też głębokiej ich indywidualizacji. Każdy konsument jest jednostką indywidualną, stąd też różnie odczuwa potrzeby i w różny sposób stara się je zaspokoić. Jest to źródło ogromnej różnorodności dostępnych na rynku produktów (rodzajów, kategorii, typów, odmian). Jedną z klasyfikacji potrzeb konsumenta, która w zasadniczy sposób wyjaśnia ich wysoką indywidualizację (co wiąże się również z wyborem określonych produktów zaspokajających potrzebę) jest klasyfikacja oparta na korzyściach, których oczekuje konsument nabywając dany produkt. Według tego kryterium wyróżnia się: potrzeby pierwotne (podstawowe, które zaspokaja konsument poprzez nabycie określonego produktu) oraz potrzeby wtórne (inaczej otoczkowe) - to „dodatkowe" potrzeby odczuwane przez konsumenta, występujące „na podwalinach” potrzeb pierwotnych; w zasadniczej mierze zależą od indywidualnych preferencji, dążeń i oczekiwań konsumenta. Ogromna różnorodność typów, odmian, wzorów produktów występujących na rynku w ramach tej samej kategorii jest właśnie wynikiem dążeń konsumentów do zaspokojenia wysoce indywidualnych potrzeb otoczkowych. Przykład zróżnicowania potrzeb konsumentów prezentuje tabela 1 .

Tabela pokazuje, że zakup określonego produktu może mieć różna wartość dla konsumentów. Konsumenci moga w odmienny sposób postrzegać np. ten sam samochód - dla jednego będzie to produkt wysokiej wartości (spełnia podstawową potrzebę), inny konsument może mieć zupełnie odmienne zdanie (co z tego, że można się tym samochodem przemieszczać, jeśli nie ma on odpowiednio bogatego wyposażenia, a ponadto ta marka nie jest dobrze postrzegana przez otoczenie).

Postrzeganie wartości produktu przez pryzmat zaspokajanych potrzeb prowadzi do sytuacji, że ten sam produkt dla jednego konsumenta ma wysoką wartość i jednocześnie może być zupełnie bezwartościowy dla drugiego ${ }^{2)}$. Typowym przykładem jest wartość, jaką stanowią dla konsumentów akcesoria dziecięce - dla matki małego dziecka wózek marki Babe Comfort jest produktem bardzo wartościowym (jedna z wiodących marek na rynku), dla osoby bezdzietnej produkt ten nie przedstawia żadnej wartości. Ogólnie rzecz ujmując postrzeganie wartości produktu z punktu widzenia konsumenta, to wypadkowa trzech wyróżników:

Tab. 1. Przykład potrzeb pierwotnych i wtórnych zaspokajanych przez samochód

\begin{tabular}{|c|l|}
\hline Rodzaj potrzeby & \multicolumn{1}{c|}{ Produkt - samochód osobowy } \\
\hline Potrzeba pierwotna & $\bullet$ potrzeba bezpiecznego, samodzielnego przemieszczania się środkiem transportu \\
\hline $\begin{array}{c}\text { Potrzeba wtórna } \\
\text { (otoczkowa) }\end{array}$ & $\begin{array}{l}\bullet \text { potrzeba prestiżu zaspokojona przez zakup samochodu określonej marki } \\
\bullet\end{array}$ \\
$\begin{array}{l}\text { powiednich parametrach technicznych i wyposażeniu) } \\
\bullet \text { potrzeba kreowania osobistego wizerunku (samochód o odpowiedniej stylistyce, kolorystyce) } \\
\bullet \text { potrzeba wyróżnienia się w społeczeństwie }\end{array}$ \\
\hline
\end{tabular}

Źródło: opracowanie własne. 
- korzyści użytkowych (inaczej mówiąc wartości użytkowej) produktu (zdolność do zaspokajania podstawowych potrzeb konsumenta związanych z użytkowaniem produktu),

- korzyści ekonomicznych (relacja ceny produktu do posiadanych zasobów finansowych konsumenta oraz relacja ceny produktu do jego jakości subiektywnie postrzeganej przez konsumenta),

- wartości indywidualnie wymaganych przez konsumenta (indywidualne pożądane i wymagane przez klienta cechy produktów związane z zaspokajaniem potrzeb otoczkowych).

Jak wspomniano, wartość dostarczana konsumentowi jest różnicą pomiędzy całkowitą wartością produktu oraz kosztem, jaki musi ponieść klient w związku z pozyskaniem tego produktu. Ogólnie można więc stwierdzić, że wartość produktu dla klienta to suma korzyści, jakich oczekuje konsument od danego produktu (usługi). Z drugiej strony, odnosząc się do aspektów związanych z zaspokajanymi potrzebami przez produkty można wyrazić są, że wartość produktu dla konsumenta to zdolność do zaspokojenia przez ten produkt indywidualnie odczuwanych potrzeb. Dlatego też właściwe jest powtarzane często twierdzenie, że z punktu widzenia przedsiębiorstwa ważne jest zrozumienie potrzeb klienta i zidentyfikowanie tego, co stanowić będzie dla niego wartość produktu. To nie firma decyduje bowiem o tym, co stanowi wartość danego produktu, ale sam klient decyduje, za co zamierza zapłacić, a za co nie. Należy więc spojrzeć „oczyma" klientów na realizowany proces wytwórczy (bez względu na to, czy jest to typowa produkcja wytwórcza, czy też realizacja usługi) i zastanowić się, które czynności w procesie, z punktu widzenia konsumenta, podnoszą czy też mogłyby podnieść wartość produktu, a które oddziałuja odwrotnie.

Produkt na rynku jest postrzegany przez konsumenta przez pryzmat dwóch rodzajów wartości. Sa to ${ }^{3)}$ :

- Wartości uniwersalne - wszystkie wartości dotyczące ogólnie odczuwanych potrzeb klienta; dotyczą zaspokojenia potrzeby na poziomie podstawowym (czyli są związane z potrzebami pierwotnymi), np. wszystkie obecne na rynku napoje zaspokajają potrzebę ugaszenia pragnienia - czyli w kontekście powyższych rozważań jednakową wartość ma Coca-Cola, jak też sok Hortexu.

- Wartości osobiste (indywidualne) - dotyczą one zaspokojenia przez produkt indywidualnych pragnień konsumenta, czyli doświadczonych i ukształtowanych przez jednostkę potrzeb. Wartości te sa postrzegane bardzo indywidualnie i wynikają z faktu hierarchizacji potrzeb i preferencji konsumentów w relacji do określonych produktów bądź marek dostępnych na rynku. Indywidualne postrzeganie napojów przez klienta determinuje zakup i - co jest oczywiste - konsument kupuje ten napój, który stanowi dla niego produkt wyższej wartości.
Wartość dla klienta nie stanowi prostej różnicy między ocena korzyści związanych $\mathrm{z}$ produktem dokonywaną przez klienta a ceną, którą musi on zapłacić za produkt. Często bywa tak, że klienci bardziej zwracają uwagę na obniżkę ceny niż na proporcjonalny przyrost korzyści. Wartość dla klienta stanowi zatem stosunek korzyści zawartych w oferowanym produkcie (usłudze) do kosztów związanych z ich uzyskiwaniem, które obejmują nie tylko cenę, ale i inne finansowe i niefinansowe obciążenia, które ponosi klient. Istotne dla jej określenia nie są obiektywne cechy produktu, lecz sposób ich postrzegania przez nabywców (wartość postrzegana) ${ }^{4}$.

Na wartość produktu składa się wiele różnych cech związanych z produktem bezpośrednio (obiektywnych: parametry techniczne, użytkowe, cena itp. i subiektywnych: atrakcyjny wygląd, dobra marka itp.), jak i pośrednio (serwis techniczny, obsługa posprzedażowa itp.). Na wartość, jaką produkt przedstawia dla konsumenta, składa się także suma zadowolenia z zaspokajanych pragnień, ambicji oraz dostosowanie się do wymagań mody. Wszak mówimy o produkcie idealnym, a więc takim, który stanowi najwyższy cel dążeń i pragnień konsumenckich. Klient świadomie płaci bowiem za wartość produktu (związaną nie tylko z jego najprostszą i najbardziej oczywistą funkcjonalnościa), lecz nabywa także pewną odmienność, wzbogacenie własnego wizerunku, pewność dobrego wyboru i dumę z jego posiadania. Także w fazie potransakcyjnej bardzo ważne jest rozumienie, co definiuje wartość i zadowolenie dla klienta. Klienci są zadowoleni, gdy ich oczekiwania są spełnione, a produkt uznają za idealny, gdy sa przekroczone. Wówczas pozostają dłużej lojalni, kupują więcej, są mniej wrażliwi na ceny i wyrażaja pozytywne opinie o firmie.

Wartość jest również oceniana w momencie zakupu i w procesie użytkowania produktu (cykl życia produktu u nabywcy). Istotna, z punktu widzenia klienta, jest korzyść dodana, którą on uzyskuje w wyniku użytkowania nabytego produktu, związana ze stopniem realizacji jego celów. Ocenie podlegają nie tylko cechy samego produktu czy usługi, ale również oceniane są relacje (związki), jakie nabywca nawiązał z firmą oferująca produkt. Odczucie satysfakcji (będące bazą lojalności klienta) powstaje wtedy, gdy rezultaty nabycia i użytkowania produktu przekraczają oczekiwania nabywcy (pobudzane m.in. przez promocję) $)^{5)}$.

Zadaniem sprawnie działającego przedsiębiorstwa jest dostarczenie klientowi satysfakcji poprzez sprzedanie mu odpowiedniej wartości. Wartość jest naczelnym elementem łańcucha sprzedaży; nierzadko jest ważniejsza od samego produktu czy usługi. Proces dostarczania wartości do nabywcy prezentuje rysunek 1 .

Satysfakcja konsumenta jest najwyższym celem związanym immanentnie z misją firmy. Satysfakcję uzyskują przedsiębiorstwa poprzez dostarczenie war-

\section{INFORMACJE $\longrightarrow$ PLAN $\longrightarrow$ DECYZJE $\longrightarrow$ WARTOŚĆ $\longrightarrow$ SATYSFAKCJA}

Rys. 1. Proces dostarczania wartości

Źródło: opracowanie własne. 
tości w postaci produktu najwyższej jakości, perfekcyjną obsługę klienta, dostawy na czas i inne elementy współpracy biznesowej. Aby jednak dostarczać wybraną wartość klientowi, firma potrzebuje zorganizowanych działań ujętych w plan. W planie określa się misję, cele strategiczne, silne i słabe strony firmy i konkurencji, dokonuje się segmentacji rynku, ustala cele i instrumentarium. Podejmowanie działań wymaga sformułowania planu, do czego niezbędne jest posiadanie odpowiedniego zasobu wiedzy w postaci zebranych informacji.

Przedsiębiorstwo rozpatruje wartość produktu głównie z punktu widzenia zyskowności. Wytyczona i realizowana przez firmę strategia marketingowa (związana z wytwarzaniem takich produktów, które w maksymalnym stopniu zaspokajają potrzeby konsumentów na rynku), ma uzasadnienie wtedy, gdy daje szansę na zwiększenie zyskowności przedsiębiorstwa. Czynniki tworzenia wartości w działalności przedsiębiorstwa produkcyjnego można podzielić na następujące grupy ${ }^{6}$ : finansowe czynniki kreujące wartość produktu, marketingowe czynniki kreujące wartość produktu oraz organizacyjne czynniki kreujące wartość produktu. Prezentacje poszczególnych elementów zamieszczono w tabeli 2.

W kontekście wartości produktu i realizacji takiej strategii produktowej, która w maksymalnym stopniu zaspokajałaby potrzeby konsumentów, istotna jest głębsza analiza czynników marketingowych. Marketingowe podejście przedsiębiorstwa do tworzenia wartości produktu oferowanego klientom na rynku opiera się na następujących przesłankach • konsument dokonujacc wyboru produktu wybiera taki, który przedstawia dla niego największą korzyść, czyli im większa korzyść produktu dla konsumenta, tym większa wartość produktu dla przedsiębiorstwa $\bullet \mathrm{z}$ punktu widzenia przedsiębiorstwa najkorzystniejsze jest budowanie stałych relacji z konsumentem, w wyniku czego powstaje zaufanie i lojalność klientów, którzy w konsekwencji stale korzystają z oferty produktowej firmy (ale jak wiadomo, bez produktu wysokiej wartości nie zbuduje się dobrych relacji z klientem!).

Decyzje dotyczące kształtowania oferty przez przedsiębiorstwo wpływają na wartość oferty dla nabywcy. Z jednej strony współokreślają użyteczność produktu postrzeganą przez klienta, z drugiej zaś oddziałują na koszty przez niego ponoszone ${ }^{7}$. Dlatego też w projektowaniu produktu wraz ze strategią dostarczania go do konsumentów należy uwzględniać sposoby podnoszenia wartości oferty postrzeganej przez klientów, starając się, aby wszystkie instrumenty marketingowe przyczyniały się do podnoszenia jej użyteczności bez nadmiernego obciążania konsumentów szeroko rozumianymi kosztami.

Na postrzeganą wartość produktu dla konsumenta wpływa szczególnie sposób wyróżniania produktu przez producenta. Pod tym terminem rozumieć należy takie nadanie produktowi dodatkowych wartości, które w zauważalny sposób wyróżniają go na rynku od konkurencji. Celem wyróżnienia jest spowodowanie, by produkt był zauważony na tle konkurencji, jak również pozycjonowanie jego w określonym segmencie rynku. Wyróżniać produkt można za pomocą wielu wymiarów i parametrów prezentowanych w tabeli 3.

Działalność przedsiębiorstwa oparta na budowaniu systemu wartości produktów w celu zapewnienia zyskowności ma również istotny wymiar konkurencyjny - należy zdać sobie sprawę, że dużą wartość może mieć

\section{Tab. 2. Czynniki kreowania wartości produktu przez przedsiębiorstwo}

\begin{tabular}{|c|c|c|}
\hline & & \\
\hline $\begin{array}{l}\text { - wzrost sprzedaży produktów } \\
\text { - marża na działalności operacyjnej } \\
\text { - inwestycje przedsiębiorstwa } \\
\text { - poziom ryzyka (inwestycji, przepły- } \\
\text { wów gotówkowych) } \\
\text { - poziom przepływów gotówkowych }\end{array}$ & $\begin{array}{l}\text { - wykreowanie silnej marki produktów } \\
\text { - odpowiedni dobór rynków } \\
\text { - zdobycie lojalnych klientów } \\
\text { - zdobycie przewagi różnicującej } \\
\text { (realizacja strategii różnicowania } \\
\text { produktu Portera) }\end{array}$ & $\begin{array}{l}\text { - umiejętności kadry zarządzającej } \\
\text { i pracowników } \\
\text { - style przywódcze kadry zarządza- } \\
\text { jącej } \\
\text { - techniki motywacyjne } \\
\text { - kluczowe zdolności (know-how } \\
\text { przedsiębiorstwa) }\end{array}$ \\
\hline
\end{tabular}

Źródło: P. DOYLE, Marketing wartości, Felberg SJA, Warszawa 2003, s. 46.

Tab. 3. Elementy wyróżniające produkt

\begin{tabular}{|l|l|l|l|}
\hline \multicolumn{1}{|c|}{ Produkt } & \multicolumn{1}{|c|}{ Zakres usług } & \multicolumn{1}{c|}{ Personel } & \multicolumn{1}{c|}{ Wizerunek produktu } \\
\hline - cechy & $\bullet$ dostawa & $\bullet$ kompetencje & $\bullet$ symbol \\
- parametry użytkowe & $\bullet$ instalacja & $\bullet$ uprzejmość & $\bullet$ środki przekazu \\
- zgodność ze standardami & $\bullet$ szkolenie odbiorcy & $\bullet$ wiarygodność & $\bullet$ atmosfera \\
- trwałość & $\bullet$ usługi doradztwa & $\bullet$ niezawodność & $\bullet$ wydarzenia \\
- niezawodność & $\bullet$ usługi naprawcze & $\bullet$ szybkość reakcji & \\
- latwość naprawy & & $\bullet$ komunikatywność & \\
- styl & & & \\
- wzór użytkowy & & & \\
\hline
\end{tabular}

Źródło: opracowanie własne. 


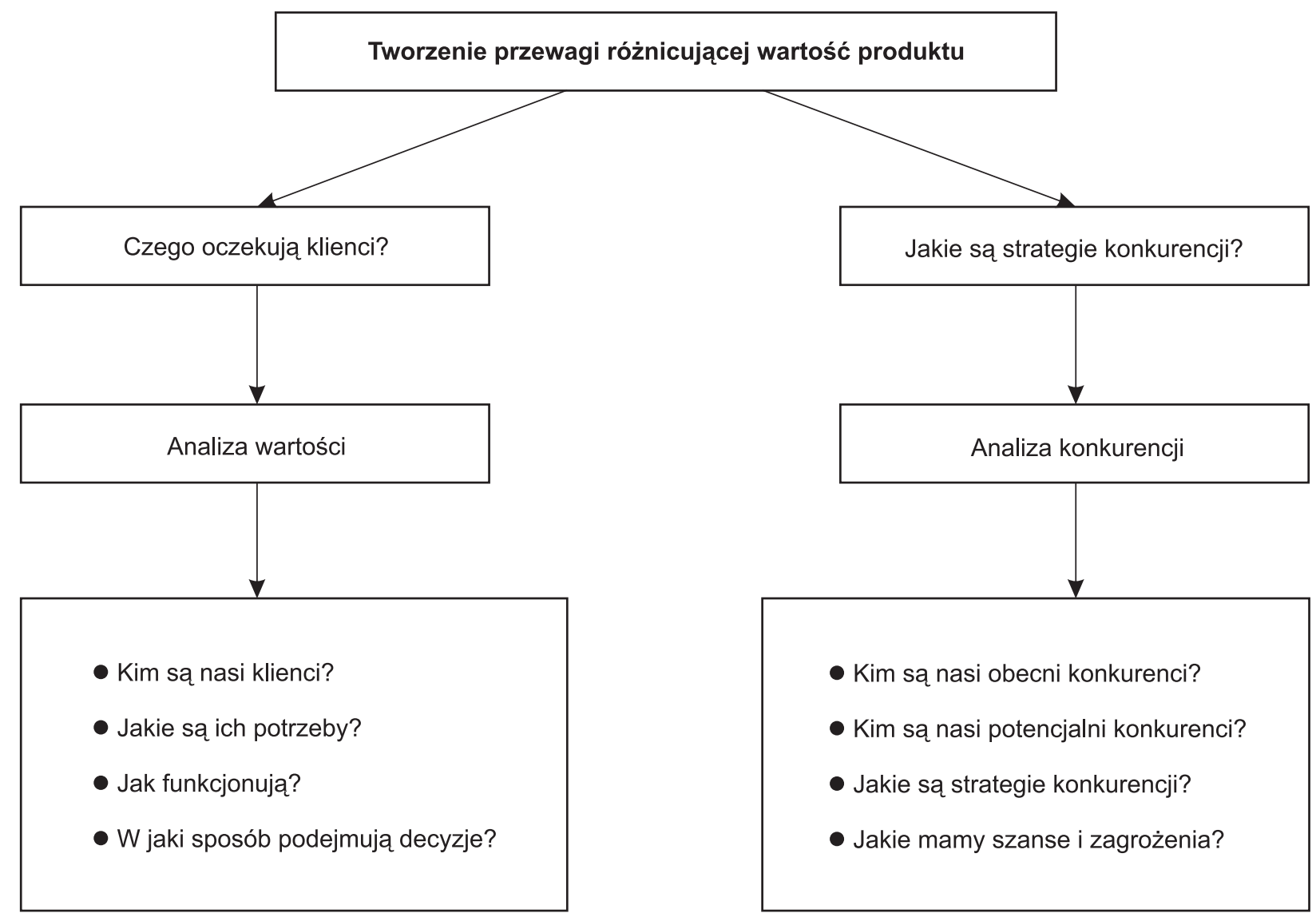

Rys. 2. Tworzenie przewagi różnicującej wartość produktu

Źródło: opracowano na podstawie: P. DOYLE, Marketing wartości, op.cit., s. 91.

dla konsumenta nasz produkt, ale również i oferta konkurencji. Stą też budowanie wartości produktu powinno się opierać również na innych obszarach działalności, nie tylko związanych z kształtowaniem oferty produktowej, lecz również poprzez budowanie z docelowymi klientami relacji, u których podłoża leży zaspokojenie ich potrzeb w sposób efektywniejszy od konkurencji. Aby to osiagnąć, przedsiębiorstwo musi uzyskać różnicujacca przewagę rynkową, czyli dostarczać produkt większej wartości niż konkurencja.

Tworzenie wartości produktu stało się obecnie priorytetowym celem działań przedsiębiorstw. Wynika to $\mathrm{z}$ intensywnej konkurencji rynkowej, jak też zwiększających się wymagań konsumentów wobec oferowanych na rynku produktów. Przedsiębiorstwo chcąc kreować jak największą wartość oferty produktowej, powinno wychodzić poza działania koncentrujące się jedynie na zwiększeniu użyteczności i funkcjonalności wyrobów, ale skupić się również na budowaniu silnej marki, zdobywaniu dużego udziału w ryn$\mathrm{ku}$, nawiązywaniu trwałych relacji z klientem, efektywnym zarządzaniu portfelem produktowym, inwestowaniu w kreatywnych pracowników oraz na rozwoju alternatywnych kanałów sprzedażowych. dr Magdalena Ankiel-Homa, mgr Tomasz Olejniczak

Katedra Marketingu Produktu Akademia Ekonomiczna w Poznaniu
PRZYPISY

1) S. MEEHAN, P. BARWISE, Czy cenicie wartość nabywcy?, [w:] Tajniki marketingu, LIBER, Warszawa 2001, s. 31.

2) Zarzadzanie produktem, red. B. SOJKIN, PWE, Warszawa 2004 , s. 31.

3) Zarzadzanie produktem, op.cit., s. 31.

4) M. SZYMURA-TYC, Zarzadzanie przez wartość dla klienta - budowa wartości firmy - www.zti.com.pl/instytut/pp / referaty/ref4 full.html, dostepp: 2.08.2004

5) M. SZYMURA-TYC, Wartość dla klienta jako źródto przewagi konkurencyjnej, „Organizacja i Kierowanie” 4/2003, s. 16.

6) P. DOYLE, Marketing wartości, Felberg SJA, Warszawa 2003, s. 46.

7) Decyzje marketingowe w przedsiębiorstwie, red. J. MAZUR, Difin, Warszawa 2002, s. 177.

\section{BIBLIOGRAFIA}

[1] DOYLE P., Marketing wartości, Felberg SJA, Warszawa 2003.

[2] KALL J., Silna marka, PWE, Warszawa 2003.

[3] SZYMURA-TYC M.,Zarzadzanie przez wartość dla klienta - budowa wartości firmy, http://www.zti.com.pl/instytut/ $\mathrm{pp} / \mathrm{referaty} / \mathrm{ref} 4$ full.html

[4] SLYWOTZKYY J., MORRISON D.J., ANDELMAN D., Strefa zysku, PWE, Warszawa 2000.

[5] Tajniki marketingu, LIBER, Warszawa 2001.

[6] Zarzadzanie produktem, red. B. SOJKIN, PWE, Warszawa 2004 . 